\title{
Kocaeli İli ve Çevresinde (1900-2016) Yılları Arasında Gerçekleşen Tarihsel Depremlerin Konumsal İstatistik Analizi
}

\author{
Özer AKYÜREK ${ }^{1 *}$, Ozan ARSLAN ${ }^{1}$ \\ ${ }^{1}$ Kocaeli Üniversitesi, Mühendislik Fakültesi, Harita Mühendisliği Bölümü, Kocaeli \\ (ozer.akyurek@kocaeli.edu.tr) ORCID ID 0000 - 0002 - 5179-0191 \\ (oarslan@kocaeli.edu.tr) ORCID ID 0000 - 0003 - 1441 - 2965
}

\begin{abstract}
Öz
Kocaeli 17 Ağustos 1999 yılında 7.4 ve sonrasındaki meydana gelen çeşitli büyüklüklerdeki artçı depremlerle gündeme gelmiştir. Sismik olarak dünyanın en diri faylarından birisi olan Kuzey Anadolu Fay hattı üzerinde bulunan Kocaeli ili, deprem araştırmaları için özel bir yere sahiptir. Deprem çalışmalarında CBS tabanlı konumsal istatistik analizlerinin kullanımı konusunda son yıllarda artış görülmektedir. Çalışmanın amacı; tarihsel süreçte (1900-2016) Kocaeli ili ve çevresinde meydana gelen depremlerin konumsal istatistik yöntemlerle incelenerek yerel ve genel örüntülerin belirlenmesi ve konumsal analizinin yapılmasıdır. Bu çalışmada seçilen deprem veri seti üzerinde; global yöntemler olan Ortalama En Yakın Komşuluk, Genel Moran I ve Getis-Ord Genel G ve yerel yöntemler olan Anselin Moran I ve Getis-Ord Gi* konumsal istatistik yöntemleri kullanılmıştır. Ayrıca meydana gelen depremlere göre yoğunluk haritalarının elde edilmesi ve riskli alanların belirlenmesi amaçlanmıştır.
\end{abstract}

Anahtar Kelimeler: Kocaeli, deprem, konumsal istatistik, kernel yoğunluk analizi

\section{Spatial Statistical Analysis of Historical Earthquakes (1900- 2016) in Kocaeli Province and Its Surroundings}

\begin{abstract}
Kocaeli province came to the fore with about big earthquake which has 7.4 magnitude on 17 August 1999 and the aftershocks of various size from after this date. Located on the North Anatolian Fault which is seismically one of the world's most active faults, this city has a special place for earthquake investigations. There has been an increased trend on the use of GIS-based spatial statistical analysis in earthquake studies in recent years. The aim of the study is to investigate local and general patterns of the earthquakes in Kocaeli province and its surroundings in the historical process between 1900 and 2016 by using spatial statistical methods. The global spatial statistical methods such as Average Nearest Neighborhood, General Moran I and Getis-Ord General Gand local ones such as Anselin Moran I and Getis-Ord Gi * methods have been used in the study. In addition, it is aimed to determine risky areas considering the earthquakes and to obtain spatial density maps.
\end{abstract}

Keywords: Kocaeli province, earthquake, spatial statistics, kernel density analysis

* Sorumlu Yazar 


\section{GİRIŞ̧}

Günümüzde tarihsel depremler ile bu depremlerin sismik veri kataloglarının konumsal örüntü teknikleri ile analizi üzerine yapılan çalışmalarda artış görülmektedir. Bu çalışmalar belli bir zaman periyodu içinde meydana gelen depremlerin global/yerel konumsal örüntülerinin belirlenmesi ve kümelenmelerin saptanması konusunda yoğunlaşmıştır. Deprem oluşumlarının modellenmesinde anlamlı olabilecek jeolojik, tektonik ve sismik aktivitelerle ilişkili olarak ortaya çıkan kümelenmelerin konumsal dağılımlarının analizi konusunda, Coğrafi Bilgi Sistemleri (CBS) tabanlı ileri araştırmalar yapılacağ1 öngörülmektedir (Shurygin, 1993; Holden ve diğ., 2003; Faenza ve diğ., 2004; Pei ve diğ., 2007; Vasudevan ve diğ., 2007; Han ve diğ., 2008; Zimeras, 2008; Pei, 2011).

Literatürde depremlerin konumsal istatistik ile incelendiği birçok çalışma bulunmaktadır. Tağıl ve Alevkayalı (2013), Ege Bölgesinde meydana gelen depremlerin konumsal istatistiklerini Moran's I ve Geary's C yöntemleri yardımıyla araştırmışlar, meydana gelen kümelenme bölgelerini belirleyerek Kernel fonksiyonu yardımıyla yoğunluk haritalarını üretmişlerdir. Bakak (2016), İzmir'in Sığacık Körfezinde gerçekleşen depremleri ortalama merkez, ağırlıklı ortalama merkez, standart uzaklık, ağırlıklı standart uzakl1k ve standart sapma elipsi analizleri ile inceleyerek bölgenin depremselliğini değerlendirmiştir. Ayrıca çalışma alanının yüksek deprem aktivitesine sahip olan bölgelerini, kernel yoğunluk fonksiyonunu uygulayarak belirlemiştir. Ayday ve diğ. (2015), Eskişehir ili genelinde meydana gelen depremleri inceleyerek, dönemsel olarak meydana gelen depremlerin Kernel fonksiyonu ile yoğunluk haritalarını üreterek çalışma alanı içerisindeki riskli bölgeleri belirlemişlerdir. Aktepe ve Aydin (2013), ortalama merkez, ağırlıklı ortalama merkez, standart uzaklık, ağırlıklı standart uzaklık, standart sapma elipsi ve nokta yoğunluğu konumsal analiz yöntemlerini kullanarak deprem merkezlerinin konumsal dağılımını belirleyerek, dağılım ve yoğunluk haritalarını üretmişlerdir. Ayrıca çalışma alanının depremselliğini inceleyerek risk oluşturabilecek alanları belirlemeye çalışmışlardır. Al-Ahmadi ve diğg. (2014), Kızıl
Denizde 1900 ile 2009 yılları arasında meydana gelen depremleri Moran's I, GetisOrd Genel G, Anselin Yerel Moran's I ve Getis-Ord Gi* yöntemlerini kullanarak konumsal olarak incelemişler, yerel ve genel örüntüleri araştırmışlar ve çalışma alanındaki kümelenmeleri belirlemeye çalışmışlardır. Ayrıca depremlerin Kernel yoğunluk analizi yöntemiyle yoğunluk haritasını çıkararak depremsellik bakımından aktif olan bölgeleri belirlemişlerdir. Affan ve diğ. (2016), Sumatra adasının Aceh bölgesinde 1921-2014 yılları arasında meydana gelen depremleri En Yakın Komşu, Moran's I, Getis-Ord Genel G, Anselin Yerel Moran's I ve Getis-Ord Gi* yöntemlerini kullanarak konumsal istatistik analizlerini yapmışlardır. Bu çalışmalarda; her bir çalışma bölgesinde meydana gelen depremlerin kümelenmeleri incelenerek, yerel ve genel konumsal örüntüleri belirlenmiştir.

Depremler ile ilgili yapılan çalışmalar büyük depremlerin belli dönemlerde zamansal ve mekânsal olarak kümelenme gösterdiğini ortaya koymuştur ve bu depremlerin birçoğu mekânsal olarak belirli fay zonları ile ilişkilidir. Büyüklüğü belirli bir değerin üzerinde olan büyük depremlerin özellikle tektonik statik stresin tetiklediği alanlarda kümelendiği de bilinmektedir. Bu çalışmada 1999 y1lında gerçekleşen 7.4 büyüklügüündeki deprem ile gündeme gelen Kocaeli ili ve çevresinde, tarihsel süreçte (1900-2016) meydana gelen depremlerin CBS tabanlı olarak konumsal analizinin yapılmas1, yerel ve global örüntülerinin belirlenmesi ve yoğunluk/dağ $11 \mathrm{~m}$ haritalarının üretilmesi amaçlanmıştır. $\mathrm{Bu}$ amaç çerçevesinde; 1900-2016 yılları arasında Kocaeli ili ve çevresinde meydana gelen ve büyüklüğü 2'nin üzerinde olan 5301 adet deprem verisi AFAD deprem merkezinden elde edilmiş ve belirtilen yöntemlerle konumsal analizi yapılmıştır. Elde edilen sonuçlardan haritalar üretilerek görsel hale getirilmiş ve risk alanları belirlenmeye çalışılmıştır. 


\section{YÖNTEM}

Kocaeli ili konum olarak $29^{\circ} 22^{\prime}-30^{\circ} 21^{\prime} \mathrm{E}$, $40^{\circ} 31^{\prime}-41^{\circ} 13^{\prime} \mathrm{N}$ coğrafi koordinatlarında, kuzeyinde Karadeniz, doğusunda Sakarya, güneyinde Bursa ve batısında İstanbul ile Yalova illeri bulunmakta olup, yüz ölçümü $3.623 \mathrm{~km} 2$ dir (Şekil 1). 2016 y1lı TÜİK nüfus verilerine göre; 1.830 .772 kişilik nüfusa ve kilometrekareye 505 kişi düşecek bir nüfus yoğunluğuna sahip Marmara bölgesinin 3 . büyük şehridir. Kuzey Anadolu Fay hattı
Paleozoyik'i ve Kocaeli Triyasını bulunduran İzmit Körfezinin kuzeyinde konumlanmış Kocaeli Yarımadas1, ikincisi ise Sakarya zonunun bir parçası olan ve İzmit Körfezinin güneyinde konumlanan Armutlu Yarımadası'dır. Kocaeli ili sınırları içerisinde kalan bölgede en kapsamlı jeolojik çalışmayı 2004 y1lında Gedik ve diğ. gerçekleştirmiştir.

Kuzey Anadolu Fayı (KAF), Karlıova'dan başlayarak Saros Körfezine kadar ulaşan doğu

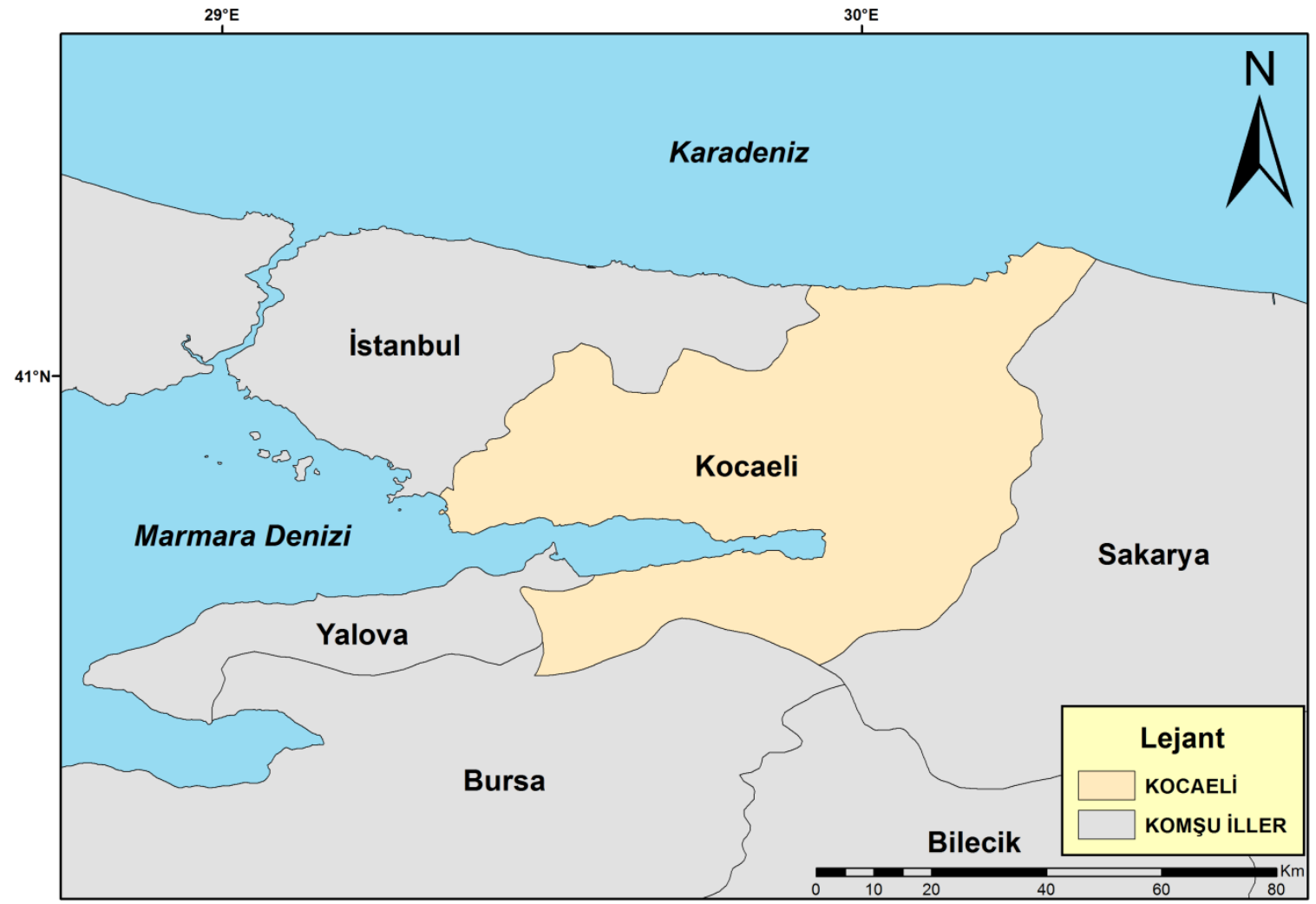

Şekil 1. Çalışma Bölgesi ve Çevresinin Genel Görünümü

üzerinde bulunması sebebiyle aktif bir deprem bölgesi olan Kocaeli ili, deprem araştırmaları için ideal bir konumdadır. 17 Ağustos 1999'da meydana gelen 7.4 lük deprem ve sonrasındaki çok sayıdaki artçı depremlerle gündeme gelmiştir.

Kocaeli İli, jeolojik yapı olarak birbirini doğal olarak tamamlayan İstanbul ve Kocaeli Yarımadası ile birlikte İstanbul zonu olarak adlandırılan tektonik yap1 üzerinde bulunmaktadır. Jeolojik pencereden bakıldığında iki önemli tektonik ve yapısal birliği bir araya getirmektedir. Bunlardan ilki Moezya platformundan koparak geldiği varsayılan ve içeriğinde genel olarak İstanbul batı yönlü, sismik açıdan aktif, dünyanın en derin fay ve tektonik yapılarından birisidir.

Toplam uzunluğu $1.200 \mathrm{~km}$ civarındadır. 100 m - $10 \mathrm{~km}$ aralığında değişen genişlikteki bir kuşak doğrultusunda doğu-batı yönlü Anadolu levhası ile Karadeniz levhası arasındaki sağ yönlü doğrultu atımlı faydır. KAF, Sapanca Gölü güneyinden İzmit Körfezi' ne kadar çok belirgin bir biçimde takip edilebilmektedir. Gölcük ilçesi dolaylarında sola atlama yaparak küçük bir çek-ayır gerçekleştirmektedir. Bu çek-ayır, SapancaGölcük bölümü ile Gölcük-Karamürsel bölümü arasında gelişmiştir. 17 Ağustos 1999 depremi, bu çek-ayır bölgeye denk gelen 
Gölcük ile Değirmendere kıyı kesiminin körfez içerisine kaymasına sebep olmuştur. Fay, Gölcük-Karamürsel aralığında kıyı hattına paralel bir biçimde deniz içerisine ilerlemektedir. Hereke-Çınarcık aralığında deniz içinde devam ederek batıya doğru yönelmektedir. Fayın güney kolu ise, GeyveMekece-İznik Gölü güneyi boyunca devam ederek, Bandırma ve Biga Yarımadası' n1 izleyip Ege Denizi' ne doğru ilerlemektedir (ÇŞB, 2011).

Çalışmada 1900-2016 yılları arasında Kocaeli ili ve çevresinde gerçekleşen, büyüklüğü 2'nin üzerinde gerçekleşen depremlerin konumsal örüntü analizinin yapılması ve konumsal dağılımlarının yorumlanması amaçlanmıştır. Bu amaçla seçilen veri kümesi üzerinde nokta örüntü analizleri, global ve yerel istatistikler kullanılacaktır.

\subsection{Konumsal İstatistik Analizleri}

Konumsal otokorelasyon bir noktada elde edilen bir özelliğin komşu konumlarda elde edilen özelliklerden bağımsız olup olmadığını belirlemek amaciyla kullanılır. Konumsal otokorelasyon pozitif ya da negatif değerler alır. Pozitif değerler komşu konumlardaki özelliklerin doğrusal olarak birbirlerini etkilediğini gösterirken (kümelenme), negatif değerler ise komşu konumlardaki özelliklerin ters olarak birbirlerini etkilediğini (dağılma) göstermektedir (Erdoğan, 2010).

\subsubsection{Ortalama ve ortanca merkez analizi}

Ortalama Merkez; çalışma alanındaki tüm verilerin $\mathrm{x}$ ve y koordinatlarının ortalamasıdır. Çalışma alanında bulunan verilerin değişikliklerini izlemek veya farklı öznitelik türlerinin dağılımlarını karşılaştırmak için kullanışlıdır.

$\bar{X}_{w}=\frac{\sum_{i=1}^{n} w_{i} x_{i}}{\sum_{i=1}^{n} w_{i}}, \bar{Y}_{w}=\frac{\sum_{i=1}^{n} w_{i} y_{i}}{\sum_{i=1}^{n} w_{i}}$

$x_{i}$ ve $y_{i}$ veri noktasının konum değerlerini, $w_{i}$ ise o konumda bulunan değerin ağırlığını temsil eder.

Ortanca merkez, dışsal değerlere karşı dayanıklı olan merkezi eğilimi ölçer. Ortanca merkez veri setindeki tüm veri noktalarıyla olan en kisa mesafedeki merkez noktasını tanımlamaktadır (Mitchell, 2005). Ortanca merkezin Ortalama merkeze göre nerede konumlandığ dağılımının gidiş yönü hakkında önemli bilgiler vermektedir (Tağıl ve Alevkayalı, 2013).

\subsubsection{Standart uzaklık}

Veri noktalarının geometrik ortalama merkez çevresindeki yoğunluğunu veya dağılma derecesini ölçer.

$\mathrm{SD}_{\mathrm{w}}=\sqrt{\frac{\sum_{i=1}^{n} w_{i}\left(x_{i}-\bar{X}_{w}\right)^{2}}{\sum_{i=1}^{n} w_{i}}+\frac{\sum_{i=1}^{n} w_{i}\left(y_{i}-\bar{T}_{w}\right)^{2}}{\sum_{i=1}^{n} w_{i}}}$

$\overline{\mathrm{X}}_{w}$ ve $\overline{\mathrm{Y}}_{w}$ ağırlıklı ortalama merkezin koordinatların, $\mathrm{w}_{\mathrm{i}}$ ise o konumda bulunan değerin ağırlığını temsil eder.

\subsubsection{Standart sapma elipsi}

Standart Sapma Elipsi çalışma alanındaki verilerin dağılım yönünü belirlemek amaciyla kullanılır. Bir dizi noktanın veya bölgenin trendini ölçmek amacıyla yaygın olarak kullanılan standart sapma elipsinde mesafe $\mathrm{x}$ ve y yönlerinde ayrı ayrı hesaplanmaktır. $\mathrm{Bu}$ iki mesafe, özellik dağılımını kapsayan bir elipsin eksenlerini tanımlarlar. Yöntem, elips eksenlerini tanımlamak için ortalama merkezden $\mathrm{x}$-koordinatlarının ve $\mathrm{y}$ koordinatlarının standart sapmasının hesaplanması şeklinde çalışmaktadır. Elips, veri setinin dağılımının uzunluğunu ve dolayısıyla belirli bir yönlendirmenin olup olmadığının gözlemlenmesini sağlar (Mitchell, 2005).

\subsubsection{Ortalama en yakın komşuluk (Average nearest neighbor)}

Ortalama En Yakın Komşuluk yöntemi, veri setinde bulunan her bir verinin en yakın komşusuyla konumu arasındaki mesafeyi ölçerek ortalamasını alır. Eğer hesaplanan ortalama mesafe, varsayımsal bir rastgele dağılımın ortalamasından daha düşükse, 
analiz edilen özelliklerin dağılımı kümelenmiş olarak veya daha büyükse özellikler dağılmış olarak kabul edilir.

$$
\mathrm{ANN}=\frac{\overline{\mathrm{D}}_{0}}{\overline{\mathrm{D}}_{\mathrm{E}}}
$$

$\overline{\mathrm{D}}_{\mathrm{0}}$ her bir öznitelik ile en yakın komşusu arasındaki gözlenen mesafenin ortalaması.

$$
\overline{\mathrm{D}}_{\mathrm{O}}=\frac{\sum_{\mathrm{i}=1}^{\mathrm{n}} \mathrm{d}_{\mathrm{i}}}{\mathrm{n}}
$$

$\overline{\mathrm{D}}_{\mathrm{E}}$ ise rastgele dağılımdaki öznitelikler için beklenen ortalama mesafedir.

$\overline{\mathrm{D}}_{\mathrm{E}}=\frac{0.5}{\sqrt{\mathrm{n} / \mathrm{A}}}$

Yukarıdaki denklemlerde, $d_{i} i$ inci özniteliğin komşusuyla olan mesafesini, $\mathrm{n}$ toplam öznitelik sayısını, A ise toplam çalışma alanını temsil etmektedir.

Ortalama En Yakın Komşuluk, her bir verinin en yakın komşusu olan veriye (yalnızca $x$ ve $y$ koordinatlarına) ve bunlarla ilişkili $\mathrm{z}$ değerlerine olan ortalama mesafeye dayanan en yakın komşu indeks değerini hesaplar. $\mathrm{Bu}$ değer 1'den küçükse, çalışma alanındaki örüntü kümelemeyi gösterir. İndeks 1 'den büyük ise, örüntü dağılım eğilimi gösterir. $Z$ skoru veya standart sapma ölçüsü, istatistiksel önemi göstermektedir. Analizde Z skoru 1.96 'dan düşük veya 1.96 'dan büyükse, örüntü sırasıyla anlamlı kümelenme veya dağılımı göstermektedir ( $\mathrm{p}<0.05)$. Z skoru 1.96 ile 1.96 arasında ise, örüntü rastgele dağılım gösterir (Mitchell, 2005).

\subsubsection{Genel Moran indeksi (Global Moran's I)}

Genel Moran İndeksi (GMI) istatistiği, olayların yerleri ve aynı zamanda olaylarla ilişkili değerler temelinde konumsal otokorelasyon derecesinin bir ölçüsüdür. GMI istatistiği belirli bir nokta örüntüsü için konumsal otokorelasyon veya dağılım derecesini gösterir (Al-Ahmadi ve diğ., 2014; Affan ve diğ., 2016).
$\mathrm{I}=\frac{\mathrm{n}}{\mathrm{S}_{0}} \frac{\sum_{\mathrm{i}=1}^{\mathrm{n}} \sum_{\mathrm{j}=1}^{\mathrm{n}} \mathrm{w}_{\mathrm{i}, \mathrm{j}} \mathrm{z}_{\mathrm{i}} \mathrm{z}_{\mathrm{j}}}{\sum_{\mathrm{i}=1}^{\mathrm{n}} \mathrm{z}_{\mathrm{i}}^{2}}$

$\mathrm{z}_{\mathrm{i}} \mathrm{i}$ inci özniteliğin ortalama değerinden olan sapmasıdır, $w_{i, j} i$ ve $j$ inci değerler arasındaki konumsal ağırlık, $\mathrm{n}$ toplam özellik sayısı, $\mathrm{S}_{0}$ tüm ağırlık değerlerinin toplamını temsil etmektedir.

$\mathrm{Z}_{\mathrm{I}}=\frac{\mathrm{I}-\mathrm{E}[\mathrm{I}]}{\sqrt{\mathrm{V}[\mathrm{I}]}}$

$\mathrm{E}[\mathrm{I}]=-1 /(\mathrm{n}-1)$

$\mathrm{V}[\mathrm{I}]=\mathrm{E}\left[\mathrm{I}^{2}\right]-\mathrm{E}[\mathrm{I}]^{2}$

denklemleriyle Z skoru hesaplanır.

Depremlerin konumsal modelinin kümelenmiş, dağılmış veya rastgele olup olmadığını belirlemek için GMI ve ilgili Z değerleri hesaplanmıştır. Konumsal otokorelasyon analizinde eğer Z skoru 1.96 'dan düşük veya 1.96 'dan büyükse, veri setinin sırasıyla dağılım veya kümelenme gösterdiği söylenebilir ( $p<0.05)$. -1.96 ve 1.96 arasındaki $\mathrm{Z}$ skorları rastgele bir dağglımın olduğunu göstermektedir.

\subsubsection{Getis-Ord Genel G (Getis-Ord General G)}

Getis-Ord Genel G (GOGG), bir çalışma alanında sıcak noktalar (yüksek değerli kümeler) veya soğuk noktalar (düşük değerli kümeler) olup olmadığının bulunması için yüksek veya düşük değerler için kümelenme boyutunu belirlemeyi amaçlar. Eğer Z skoru değeri pozitif ise, gözlenen GOGG değeri, beklenen GOGG değerinden daha büyüktür, bu nedenle ilgili özellik için yüksek değerlerin çalışma alanında kümelenmeler oluşturduğu söylenebilir. Eğer $\mathrm{Z}$ skoru değeri negatif ise, gözlenen GOGG değeri beklenen değerden daha küçüktür, bu da çalışma alanında düşük değerlerin kümelenmiş olduğunu göstermektedir (Al-Ahmadi ve diğ., 2014; Affan ve diğ., 2016).

$\mathrm{G}=\frac{\sum_{\mathrm{i}=1}^{\mathrm{n}} \sum_{\mathrm{j}=1}^{\mathrm{n}} \mathrm{w}_{\mathrm{i}, \mathrm{j}} \mathrm{x}_{\mathrm{i}} \mathrm{x}_{\mathrm{j}}}{\sum_{\mathrm{i}=1}^{\mathrm{n}} \sum_{\mathrm{j}=1}^{\mathrm{n}} \mathrm{x}_{\mathrm{i}} \mathrm{x}_{\mathrm{j}}}, \forall \mathrm{j} \neq \mathrm{i}$

$x_{i}$ ve $x_{j} i$ inci ve $j$ inci verilere ait bilgiler, $w_{i, j} i$ ve $\mathrm{j}$ değerleri arasındaki ağırlık katsayısı, $n$ toplam veri sayısını temsil etmektedir. 


\subsubsection{Kernel yoğunluk analizi}

Kernel Yoğunluk Analizi, veri seti yoğunluğunu hesaplayarak verilerin dağılımının birinci derece özelliklerini analiz etmek için parametrik olmayan bir konumsal enterpolasyon yöntemidir (Al-Ahmadi ve diğ., 2014). Yöntem; belirlenen bir yarıçap değerine sahip çember içerisinde kalan veri seti noktalarının yoğunluğu ile çemberin merkezinden uzaklaştıkça değişen noktasal yoğunluğu tanımlamaktadır (Bakak, 2016; Ayday ve di ̌̆., 2015).

$$
\lambda(\mathrm{s})=\sum_{\mathrm{i}=1}^{\mathrm{n}} \frac{1}{\pi \mathrm{r}^{2}} \mathrm{k}\left(\frac{\mathrm{d}_{\mathrm{is}}}{\mathrm{r}}\right)
$$

$\lambda(s)$ s konumundaki yoğunluk değerini, $r$ tanımlanan yarıçap değerini, $\mathrm{n}$ toplam veri seti nokta sayısını, $\mathrm{k}$ i noktasının ağırlık değerini, $\mathrm{d}_{\text {is }}$ ise $\mathrm{i}$ noktas1 ile $\mathrm{s}$ noktasi arasındaki mesafeyi tanımlamaktadır.

\subsubsection{Anselin yerel Moran's I}

Moran's I yöntemi genel ölçekli olup çalışma alanının genelinde dağılımın konumsal bağımlılık düzeyini ölçmektedir. Ancak çalışma alanının içerisinde dağılımın hangi bölgelerde kümelendiğini yerel olarak belirleyememektedir. Anselin Yerel Moran's I birbirine benzeyen ve benzemeyen değişkenlerin meydana getirdiği kümelenmelerin belirlenmesinde kullanılan yerel bir yöntemdir. İstatistiksel olarak sonuç değeri yüksek ise; ilgili bölgenin etrafındaki alanlarda da yüksek veya düşük değerlerin kümelenme oluşturduğunu göstermektedir. Eğer sonuç değeri düşük çıkmış ise birbirine benzemeyen değerlerin bir araya geldiğini göstermektedir. Z skoru değeri de çıkan sonuç değerinin istatistiksel anlamlılığ1 hakkında bilgi vermektedir (Yakar, 2011). Anselin Yerel Moran's I aşağıdaki şekilde tanımlanır;

$$
I_{\mathrm{i}}=\frac{\mathrm{x}_{l}-\overline{\mathrm{X}}}{\mathrm{S}_{i}^{2}} \sum_{\mathrm{j}=1_{j} \mathrm{j} \neq \mathrm{i}}^{\mathrm{n}} W_{i, j}\left(\mathrm{x}_{j}-\overline{\mathrm{X}}\right)
$$

$\mathrm{x}_{\mathrm{i}}$ veri setindeki i. özelliğin değeri, $\overline{\mathrm{X}}$ ilgili değerin ortalaması (deprem büyüklüklerinin ortalaması), $\mathrm{w}_{\mathrm{i}, \mathrm{j}}$, $\mathrm{i}$ inci ve $\mathrm{j}$ inci veri noktaları arasındaki ağırlık değerini temsil etmektedir. Farklı komşuluk/yakınlık kriterlerine bağlı olarak tanımlanabilen (kesikli, sürekli vb.) ve tüm noktalar arasındaki rölatif konum ölçüsünü veren bir "konumsal ağırlık matrisi" olarak düşünülebilir.

\subsubsection{Getis-Ord Gi*}

Getis-Ord Gi* yöntemi veri setinde bulunan sicak nokta (hot spots) ve soğuk nokta (cold spots) değerlerin konumsal olarak nerelerde kümelendiğini belirler. İstatistiksel olarak hesaplanan $\mathrm{Z}$ skoru ne kadar büyükse veri setinde bulunan yüksek/sıcak değerlerin kümelenmesi o derecede yüksektir. Diğer yandan $\mathrm{Z}$ skoru ne kadar küçükse düşük değerlerin kümelenmesi o oranda fazladır. Hesaplanan $\mathrm{Gi}^{*}$ değeri sifira yakınsa hesaplanan özelliğin komşuluğunda yüksek veya düşük değerlerin olmadığı söylenebilir.

$$
\mathrm{G}_{\mathrm{i}}^{*}=\frac{\sum_{\mathrm{j}=1}^{\mathrm{n}} \mathrm{w}_{\mathrm{i}, \mathrm{j}} \mathrm{x}_{\mathrm{j}}-\overline{\mathrm{X}} \sum_{\mathrm{j}=1}^{\mathrm{n}} \mathrm{w}_{\mathrm{i}, \mathrm{j}}}{\mathrm{s}}
$$

$\mathrm{x}_{\mathrm{j}}$ veri setindeki $\mathrm{j}$ inci özelliğin değerini, $\mathrm{w}_{\mathrm{i}, \mathrm{j}}, \mathrm{i}$ inci ve $\mathrm{j}$ inci veri noktaları arasındaki konumsal ağırlık değerini/matrisini tanımlamaktadır. 


\section{BULGULAR}

Çalışmada 1900-2016 yılları arasında Kocaeli ili ve çevresinde gerçekleşen, büyüklügü 2'nin üzerinde 5301 adet deprem verisi kullanılmıştır (Şekil 2). Kullanılan veri setinin özelliklerini yansıtan genel özet istatistik bilgileri Tablo 1'de gösterilmektedir.

Buna göre tablolardan tüm veri seti için elde edilen değerler göz önüne alındığında Ortalama En Yakın Komşuluk, Moran's I ve Getis Ord Genel G istatistiği yöntemlerinin sonuçları sırasıyla $0.69, \quad 0.09$ ve 0.05 değerlerini aldığı görülmektedir.

Tablo 1'den de görüldüğü gibi en yüksek deprem sayıs1 \%75'lik oranla 2 ile 2.9 büyüklükleri arasındaki depremlerde görülmüștür. İkinci olarak 3 ile 3.9 büyüklükleri arasındaki depremler \%21'lik oranla gerçekleşmiştir. $4 \leq \mathrm{M} \leq 4.9$ büyüklük aralığındaki depremler tüm depremlerin \%2.9 luk bölümü oluşturmaktadır. \%0.32 lik kısmı oluşturan 17 adet $5 \leq \mathrm{M} \leq 7.4$ büyüklüğü aralığındaki depremlerin sayısı da oldukça fazladır. Gerçekleşen 5301 adetlik deprem Kocaeli bölgesinin deprem ve depremsellik bakımından oldukça aktif bir bölge olduğunu göstermektedir.

Global konumsal istatistik yöntemleri olan Ortalama En Yakın Komșu, Moran's I ve Getis Ord Genel $G$ istatistik yöntemlerinin sonuçları Tablo 2, 3 ve 4' te verilmektedir. Konumsal istatistik yöntemlerinde indeks değerlerinin 1' in altında değer alması veri setinin konumsal olarak kümelendiği anlamına gelmektedir (Tağıl ve Alevkayalı, 2013; Al-Ahmadi ve diğ., 2014; Affan ve diğ., 2016). Moran I için, sıfira yakınsa rassal; 1'e yaklaştıkça pozitif otokorelasyon (kümelenme); -1'e yaklaştıkça negatif otokorelasyon (dağılmış) örüntüden bahsedilir. Ayrica anlamlılık testine bakılmalıdır.

Tablolarda verilen değerler 1900-2016 yılları arasında Kocaeli ili ve çevresinde meydana gelen depremlerin konumsal olarak birbirleriyle ilişkili/bağımlı olduğunu göstermektedir.

Tablo 1. 1900-2016 yılları arasında Kocaeli ve çevresinde meydana gelen depremlerin tanımsal istatistikleri

\begin{tabular}{lcccccc}
\hline Büyüklük & $\begin{array}{c}\text { Deprem } \\
\text { Sayısı }\end{array}$ & Deprem \% & $\begin{array}{c}\text { Minimum } \\
\text { Büyüklük }\end{array}$ & $\begin{array}{c}\text { Maksimum } \\
\text { Büyüklük }\end{array}$ & $\begin{array}{c}\text { Ortalama } \\
\text { Büyüklük }\end{array}$ & $\begin{array}{c}\text { Standart } \\
\text { Sapma }\end{array}$ \\
\hline $\mathbf{2} \leq \mathbf{M} \leq \mathbf{2 . 9}$ & 4011 & 75.66 & 2 & 2.9 & 2.6 & 0.2 \\
$\mathbf{3} \leq \mathbf{M} \leq \mathbf{3 . 9}$ & 1120 & 21.13 & 3 & 3.9 & 3.2 & 0.2 \\
$\mathbf{4} \leq \mathbf{M} \leq \mathbf{4 . 9}$ & 153 & 2.89 & 4 & 4.9 & 4.3 & 0.2 \\
$\mathbf{5} \leq \mathbf{M} \leq 7.4$ & 17 & 0.32 & 5 & 7.4 & 5.7 & 0.7 \\
$\mathbf{2} \leq \mathbf{M} \leq \mathbf{7 . 4}$ & 5301 & 100.00 & 2 & 7.4 & 2.8 & 0.5 \\
\hline
\end{tabular}




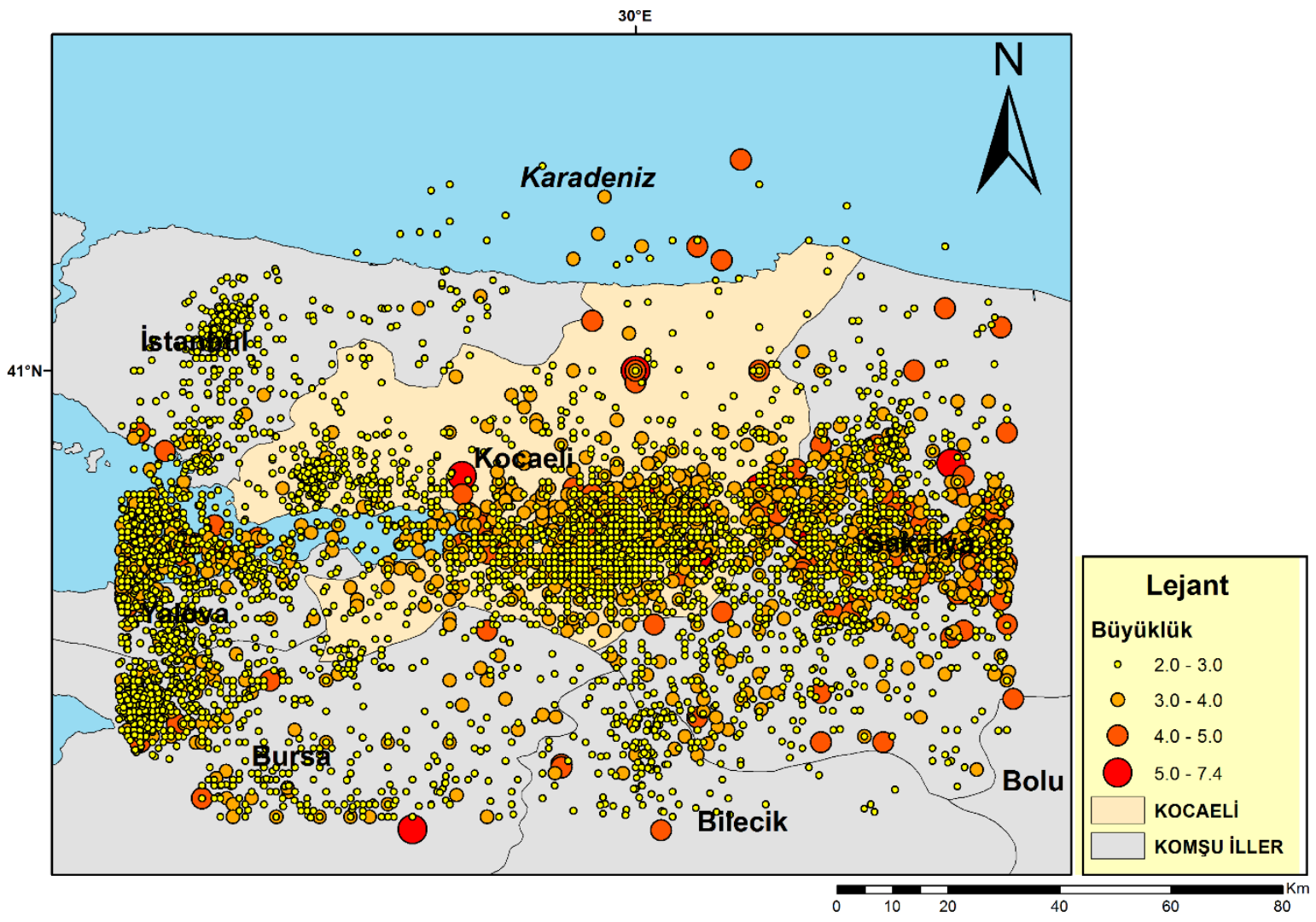

Şekil 2. 1900-2016 Yılları Arasında Kocaeli İli ve Yakın Çevresinde Gerçekleşen Depremler

Tablo 2. Ortalama En Yakın Komşuluk yöntemi istatistikleri

\begin{tabular}{ccccc}
\hline Büyüklük(M) & İndeks & Z Skor & P değeri & $\begin{array}{c}\text { Kümelenme } \\
\text { Durumu }\end{array}$ \\
\hline $\mathbf{2} \leq \mathbf{M} \leq \mathbf{2 . 9}$ & 0.71 & -34.33 & 0.00 & Kümelendi \\
$\mathbf{3} \leq \mathbf{M} \leq \mathbf{3 . 9}$ & 0.69 & -19.48 & 0.00 & Kümelendi \\
$\mathbf{4} \leq \mathbf{M} \leq \mathbf{4 . 9}$ & 0.66 & -7.99 & 0.00 & Kümelendi \\
$\mathbf{5} \leq \mathbf{M} \leq \mathbf{7 . 4}$ & 1.13 & 1.01 & 0.31 & Rastgele \\
$\mathbf{2} \leq \mathbf{M} \leq \mathbf{7 . 4}$ & 0.69 & -43.44 & 0.00 & Kümelendi \\
\hline
\end{tabular}

Tablo 3. Moran's I yöntemi istatistikleri

\begin{tabular}{ccccc}
\hline Büyüklük(M) & İndeks & Z Skor & P değeri & $\begin{array}{c}\text { Kümelenme } \\
\text { Durumu }\end{array}$ \\
\hline $\mathbf{2} \leq \mathbf{M} \leq \mathbf{2 . 9}$ & 0.07 & 58.68 & 0.00 & Kümelendi \\
$\mathbf{3} \leq \mathbf{M} \leq \mathbf{3 . 9}$ & 0.01 & 4.61 & 0.00 & Kümelendi \\
$\mathbf{4} \leq \mathbf{M} \leq \mathbf{4 . 9}$ & 0.01 & 0.91 & 0.36 & Rastgele \\
$\mathbf{5} \leq \mathbf{M} \leq \mathbf{7 . 4}$ & -0.05 & 0.13 & 0.89 & Rastgele \\
$\mathbf{2} \leq \mathbf{M} \leq \mathbf{7 . 4}$ & 0.09 & 82.00 & 0.00 & Kümelendi \\
\hline
\end{tabular}


Tablo 4. Getis Ord Genel G yöntemi istatistikleri

\begin{tabular}{|c|c|c|c|c|}
\hline Büyüklük(M) & İndeks & Z Skor & $P$ değeri & $\begin{array}{c}\text { Kümelenme } \\
\text { Durumu }\end{array}$ \\
\hline $2 \leq \mathrm{M} \leq 2.9$ & 0.06 & 5.44 & 0.00 & $\begin{array}{c}\text { Yüksek } \\
\text { Kümelenme }\end{array}$ \\
\hline $3 \leq \mathrm{M} \leq 3.9$ & 0.11 & 0.76 & 0.44 & Rastgele \\
\hline $4 \leq M \leq 4.9$ & 0.13 & 0.87 & 0.38 & Rastgele \\
\hline $5 \leq \mathrm{M} \leq 7.4$ & 0.65 & 0.25 & 0.80 & Rastgele \\
\hline $2 \leq \mathrm{M} \leq 7.4$ & 0.05 & 5.50 & 0.00 & $\begin{array}{c}\text { Yüksek } \\
\text { Kümelenme }\end{array}$ \\
\hline
\end{tabular}

Ortalama En Yakın komşu yöntemine göre yapılan analizde meydana gelen depremlerden $5 \leq \mathrm{M} \leq 7.4$ büyüklüğüne sahip depremler rastgele dağılım göstermiş, bunun dişındaki bütün depremler ise kümelenme özelliği göstermişlerdir (Tablo 2). Moran's I yöntemine göre meydana gelen depremler incelendiğinde $4 \leq M \leq 4.9$ ve $5 \leq M \leq 7.4$ büyüklüklerine sahip depremler rastgele dağılım sergilemişler, bunlar dışındaki depremler ise kümelenme özelliği göstermişlerdir (Tablo 3). Getis Ord Genel G yönteminde ise sadece $2 \leq \mathrm{M} \leq 2.9$ büyüklüğüne sahip depremler yüksek kümeleme özelliği göstermiş, bunun dışındaki tüm büyüklüklere sahip depremler ise rastlantısal dağılım özelliğgi göstermişlerdir (Tablo 4). Buna göre genel konumsal istatistik yöntemleri birbirleri ile karşılaştırıldığında farklı sonuçlara ulaşıldığı görülmektedir. Bu durumda çalışma alanı içerisindeki kümelenmeleri bölgesel ölçekte belirleyebilen Getis Ord Gi* ve Anselin Yerel Moran's I gibi yerel konumsal istatistik yöntemlerinden faydalanılabilinir. Getis Ord $\mathrm{Gi}^{*}$ istatistiği yerel ortalama ile genel ortalamay karşılaştırarak belirli bir mesafe (veya band) içerisinde kalan tüm veri seti özelliklerini hesaba katarak yüksek ve düşük değerdeki özelliklerin çalışma alanı içerinde nerelerde kümelendiğini belirleyebilmektedir. Bölgesel olarak otokorelasyonun mevcut olmadığ 1 veya lokal olarak değişkenliğin mevcut olduğu durumlarda; Anselin Yerel Moran's I belirli bir alanda benzer değerlere sahip öznitelik değerlerini tanımlamak için kullanılır. Yöntem birbirine komşu tüm veri seti özelliklerinden ortalama bir değer belirler ve komşu değerlerin bu ortalama değerden farkını alarak çalışır. Bu prensip ile çalışma alanındaki bölgesel komşulukları/ değişkenlikleri belirleyebilmektedir (İlçi, 2013).

Şekil 3'te yerel konumsal istatistik yöntemlerinin (Anselin Moran's I ve Getis Ord $\mathrm{Gi}^{*}$ ) sonuçları gösterilmektedir. Buna göre Şekil 3-a'da Anselin Moran's I yöntemine göre Kocaeli ve Sakarya illeri şehir merkezlerinde yüksek değerlerin kümelendiği, Dilovas1, Gebze ilçelerinde, Yalova'nın güneyinde, İstanbul'un doğusunda ve Bilecik ilinin kuzeyinde kalan bölümlerde düşük değerlerin kümelendiği görülmektedir. Benzer şekilde Şekil 3-b'de Getis Ord Gi* yönteminin de aynı bölgelerde benzer sonuçlar verdiği görülmektedir. Kocaeli ve Sakarya illerinin şehir merkezlerinde yüksek değerlerin (sıcak noktalar) kümelendiği, diğer bölgelerde de (Yalova'nın güneyi, İstanbul'un doğusu, Bilecik'in kuzeyi ve Dilovası ve Gebze ilçeleri) düşük değerlerin (soğuk noktalar) kümelendiği görülmektedir. 


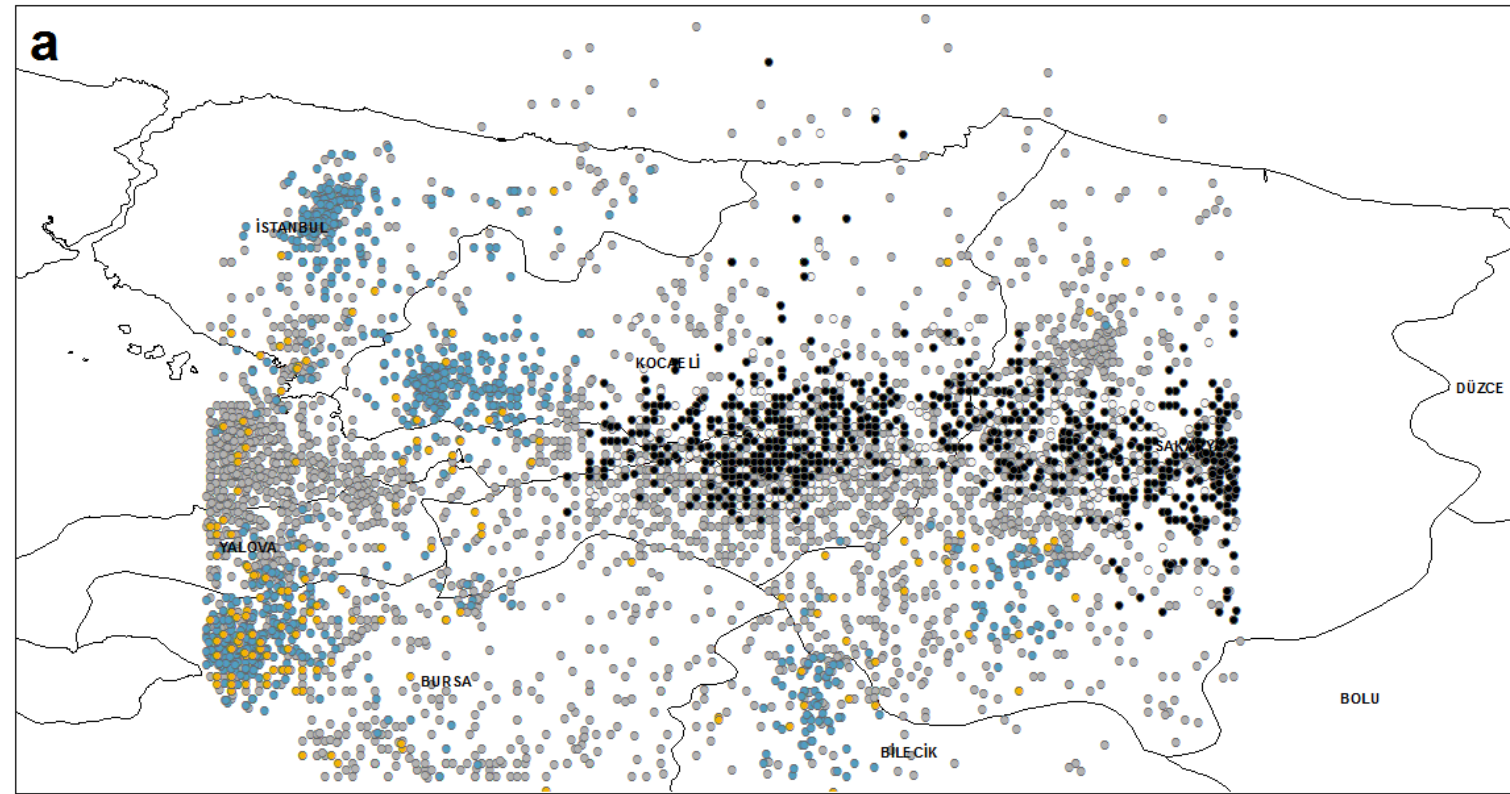

\section{Lejant}

Anselin Moran's I

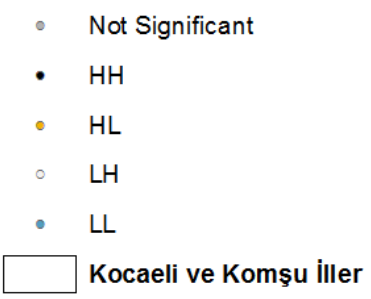

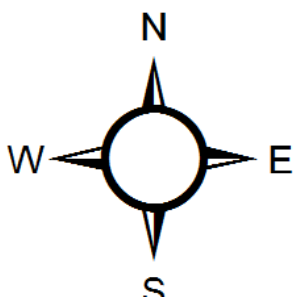

60

\section{Lejant}

\section{GetisOrdGi}

$-\quad<-2.58$ Std. Dev.

- $\quad-2.58--1.96$ Std. Dev.

- $\quad-1.96--1.65$ Std. Dev.

- $\quad-1.65-1.65$ Std. Dev

- $1.65-1.96 \mathrm{Std}$. Dev.

- $1.96-2.58$ Std. Dev.

- $\quad>2.58$ Std. Dev. Kocaeli ve Komşu iller

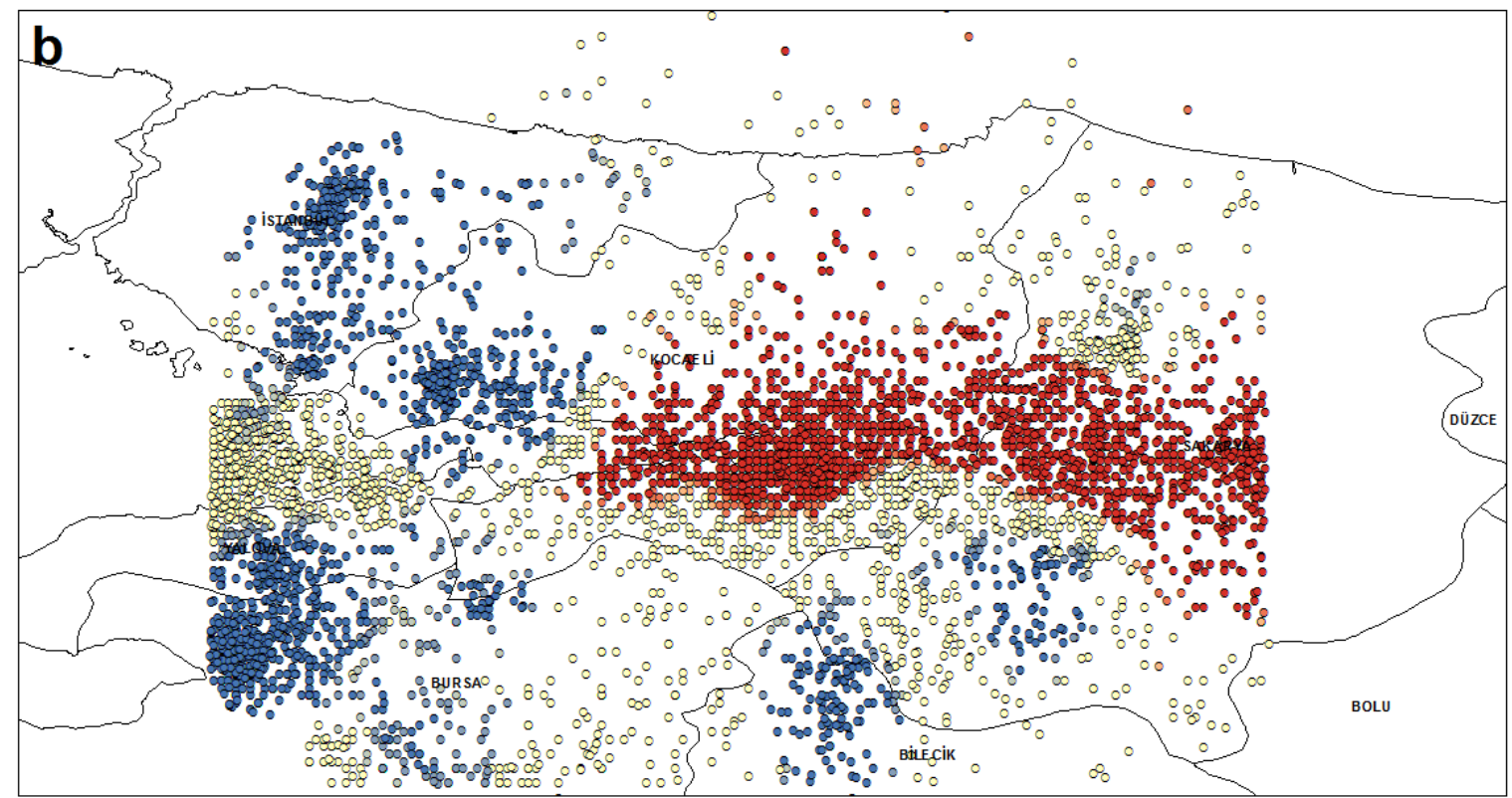

Şekil 3. Yerel Konumsal İstatistik Yöntemleri; a) Anselin Moran’s I, b) Getis Ord Gi* 

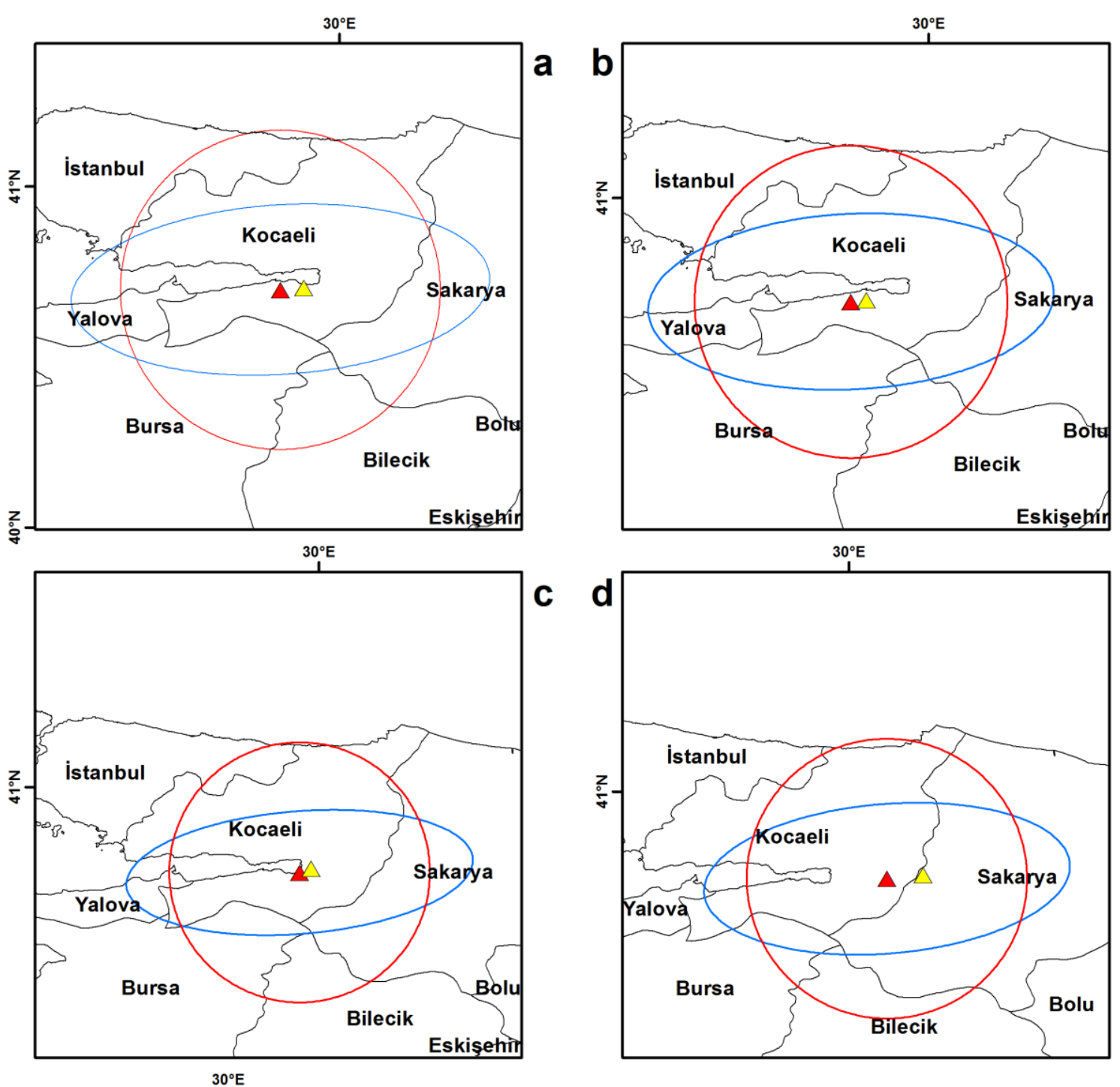

c d
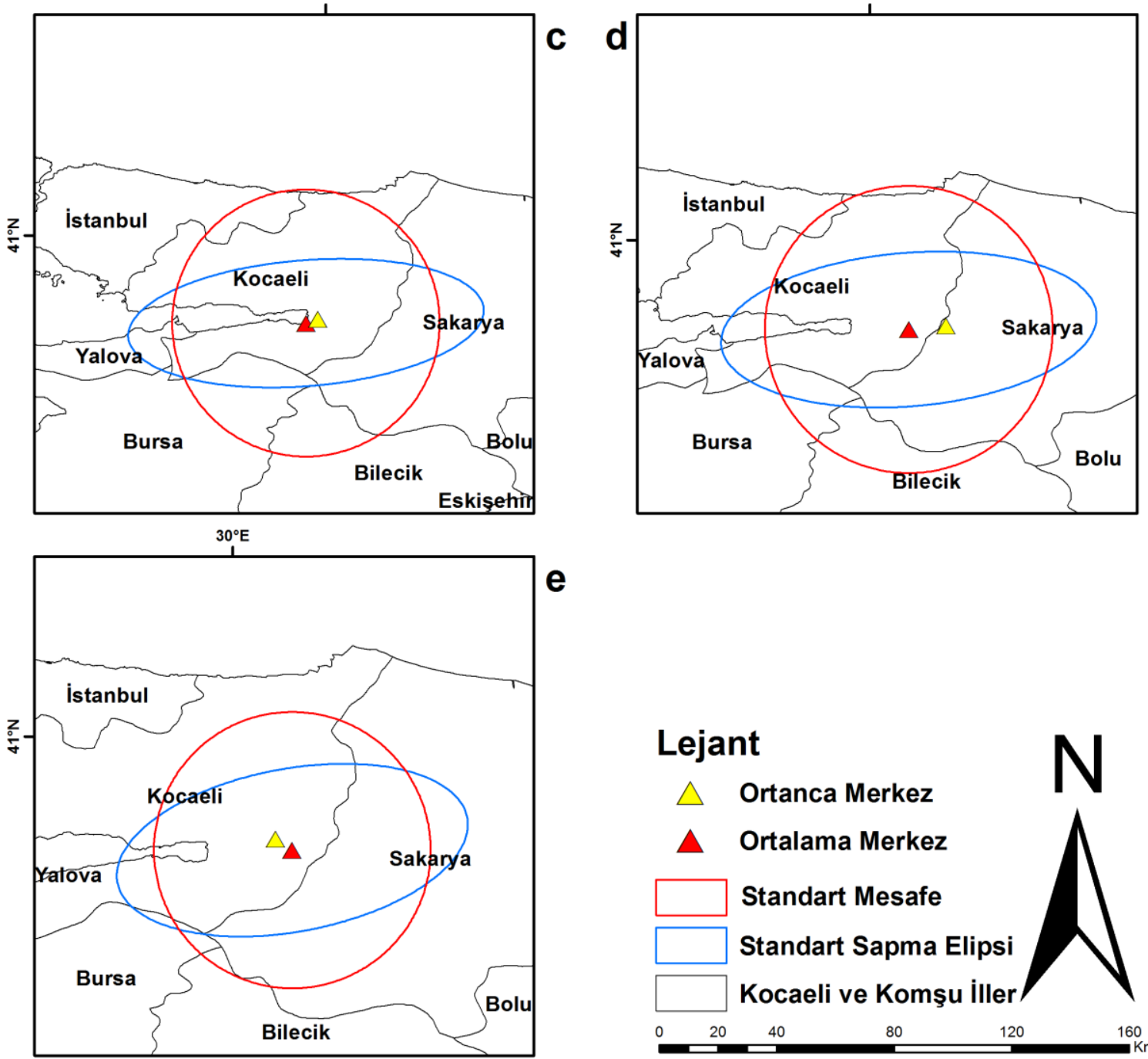

e

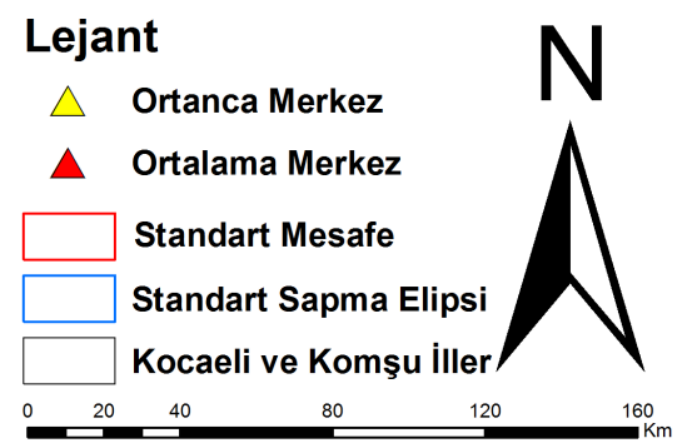

Şekil 4. Ortalama, Ortanca Merkezler, Standart Mesafe ve Standart Sapma Elipsleri; a) Tüm depremler, b) $2 \leq \mathrm{M}<3$, c) $3 \leq \mathrm{M}<4$, d) $4 \leq \mathrm{M}<5$, e) $5 \leq \mathrm{M} \leq 7.4$ 
Şekil 4 a-e'de meydana gelen depremlerin ortalama ve ortanca merkezleri, Standart mesafeleri ve 1 standart sapmaya sahip standart sapma elipsleri gösterilmektedir. Ortalama ve Ortanca Merkez analizlerinde ağırlık değeri olarak gerçekleşen depremlerin büyüklükleri kullanılmıştır. Buna göre Ortalama Merkez tüm depremler için 29.8271 Boylam - 40.6977 Enlem koordinatlarında, Ortanca Merkez ise 29.8958 Boylam 40.7041 Enlem koordinatlarında olduğu belirlenmiştir (Şekil 4-a). Depremlerin büyüklük değerleri arttıkça ortalama merkezin batıdan doğuya doğru kaydığı açık bir şekilde görülebilmektedir. Ortanca merkezin, ortalama merkeze göre konumlanması depremlerin gidiş yönü hakkında bilgi vermesi bakımında önem arz etmektedir. Şekil 4-e dışındaki bütün ortanca merkezler, ortalama merkezlerin doğusunda konumlanmıștır. Şekil 4-e'de ise ortanca merkez, ortalama merkezin kuzey batısinda bulunmaktadır. Standart mesafe çemberleri deprem merkezlerinin ortalama merkezden ne kadar uzağa yayıldığı hakkında bilgi vermektedir. Depremlerin büyüklük değerleri ağırlık katsayısı olarak analize katılmış ve standart uzaklık bilgisi elde edilmiştir. Gerçekleşen analiz sonucunda standart uzaklık çemberinin çalışma alanındaki tüm verileri içine alması, deprem merkezlerinin belirli bir konumda gruplanmayarak çalışma alanına yayılmış bir yapı sergiledikleri sonucunu ortaya çıkarmaktadır. Bütün standart mesafe çemberleri Kocaeli ili genelini kapsadığından, deprem merkezlerinin belirli bir alanda kümelenmedikleri, il sınırı geneline dağıldıkları söylenebilir. Standart sapma elipsleri incelendiğinde ortaya çıkan elipslerin hepsinin doğu batı yönünde olduğu bunun sebebinin ise Kuzey Anadolu Fay hattının da bu doğrultuda olması ve meydana gelen birçok depremin bu fay hattının üzerinde gerçekleşmesi olarak gösterilebilir (Şekil 4-a).

Şekil 5 a-e depremlerin büyüklüklerine göre kernel yoğunluk haritalarını göstermektedir. Şekil 5-a tüm deprem verilerinin yoğunluğunu göstermektedir. Şekil 5'te de görüleceği gibi en yoğun olan alan 17 Ağustos 1999 y1lında gerçekleşen 7.4 büyüklüğündeki depremin merkezi ve çevresi olan bölge olduğu görülmektedir. Ayrıca Yalova'nın güney bölgesi Bursa sınırları içinde kalan bölgede de yoğun depremlerin gerçekleştiği

görülmektedir. Şekil 5-b $2 \leq \quad M \quad<3$ büyüklüğündeki depremlerin yoğunluk haritasını göstermektedir. Şekil 5-a ile benzerlik göstermekle birlikte deprem yoğunlukları genellikle Kocaeli şehir merkezinde ve Yalova'nın güneyinde yoğunlaştığını söylemek mümkündür. Şekil 5c'de $3 \leq \mathrm{M}<4$ büyüklüğündeki depremlerin genellikle Kocaeli şehir merkezi genelinde gerçekleştiği ayrıca Kandıra ilçesinin belirli bir noktasında meydana geldiği görülmektedir. Şekil 5-d'de $4 \leq \mathrm{M} \quad<5$ büyüklüğüne sahip depremlerin yoğunluk haritası göstermektedir. Depremlerin çalışma alanı geneline yayıldığı, bunun yanında Sakarya ili genelinde daha yoğun şekilde meydana geldiklerini söylemek mümkündür. 

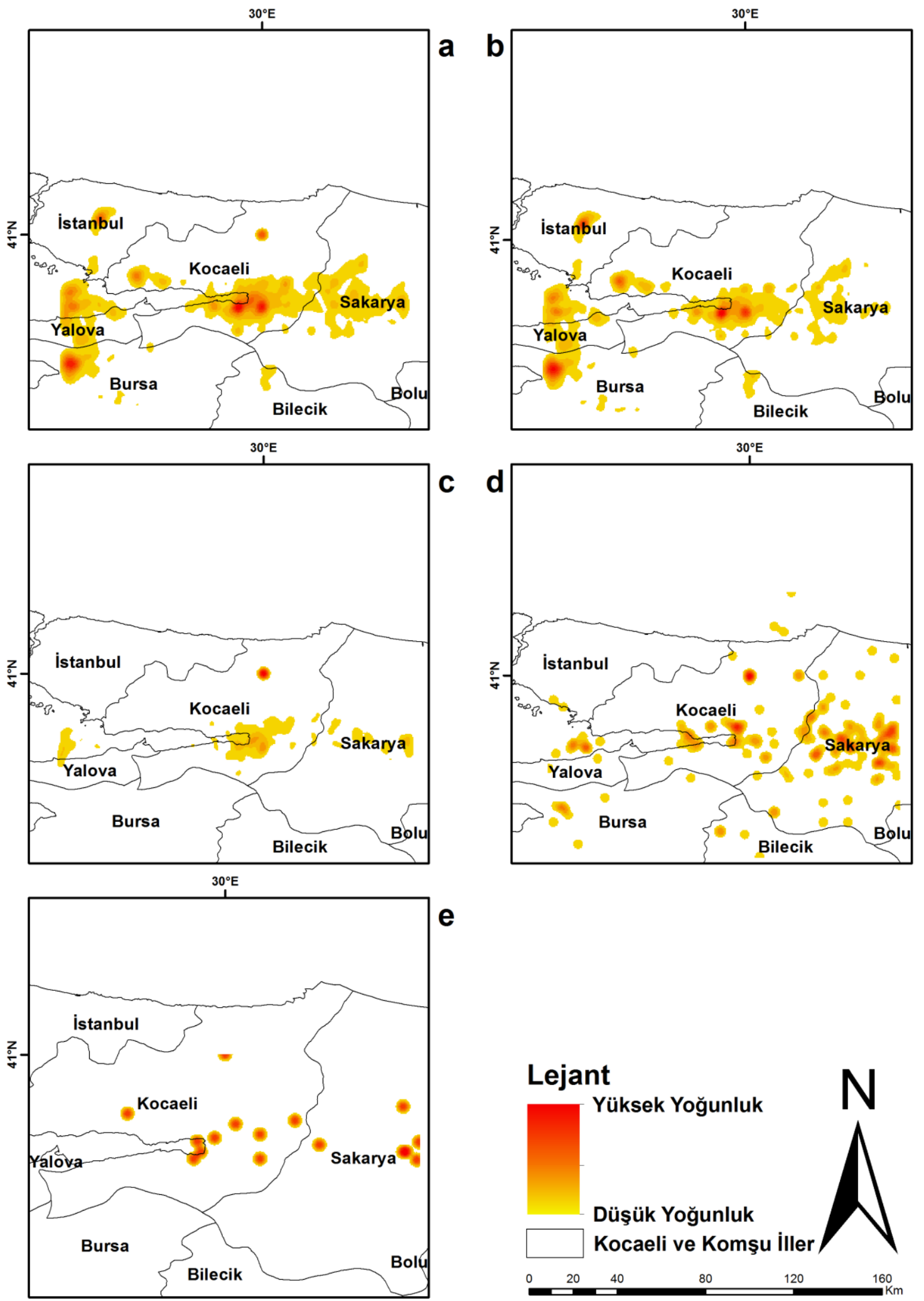

e
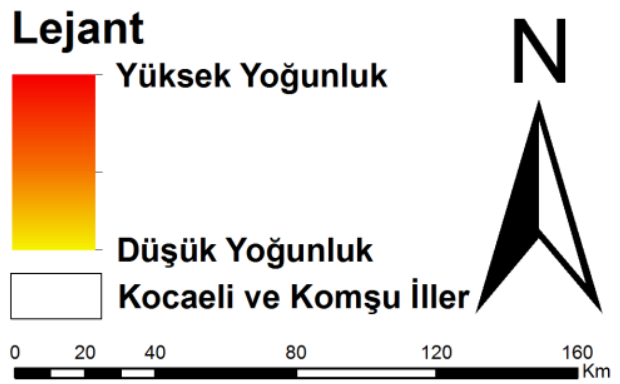

Şekil 5. Kernel Yoğunluk Haritaları; a) Tüm depremler, b) $2 \leq M<3$, c) $3 \leq M<4$, d) $4 \leq M<5$, e) $5 \leq$ $\mathrm{M} \leq 7.4$ 


\section{SONUÇLAR ve TARTIȘMA}

Kocaeli ili ve çevresinde meydana gelen tarihsel süreçteki depremlerin CBS tabanlı konumsal analizinin yapılmasının amaçlandığı bu çalışmada; 1900-2016 yılları arasında Kocaeli ili ve çevresinde meydana gelen, büyüklüğü 2'nin üzerindeki depremler incelenmiş, yerel ve global konumsal istatistik analizleri uygulanarak meydana gelen depremlerin incelemesi yapılmıştır. Konumsal Analiz yöntemlerinin (genel ve yerel) tümü deprem verilerini kümeleyerek, meydana gelen bu depremlerin konumsal olarak birbirleriyle ilişkili/ bağımlı olduğunu ortaya çıkarmıştır. 17 Ağustos 1999 yılında meydana gelen büyük Kocaeli depreminin merkezi etrafında yüksek büyüklüğe sahip depremlerin kümelendiği görülmüş, Yalova'nın güneyi, İstanbul'un doğusu, Bilecik'in kuzeyi ve Dilovası ve Gebze ilçeleri çevresinde ise düşük büyüklüğe sahip depremlerin kümelenme özelliği gösterdiği belirlenmiştir. Meydana gelen depremlerin ortalama ve ortanca merkezleri incelenmiş ve depremlerin büyüklük değerleri arttıkça ortalama merkezin batıdan doğuya doğru kaydığg görülmüştür. Ortanca merkezin, ortalama merkeze göre nerede konumlandığ1 deprem merkezlerinin dağılımının gidiş yönü hakkında önemli bilgiler vermektedir. Ortanca merkezlerin analizler sonrasinda ortalama merkezin doğusunda konumlandığ 1 belirlenmiştir. Standart mesafe çemberlerinin çalışma alanının tümünü kapsaması gerçekleşen depremlerin çalışma alanın geneline yayıldığını ortaya çıkarmıştır. Standart Sapma Elipsinin doğu batı yönlü çıkması ve Kuzey Anadolu Fay hattı ile çakışması depremlerin genellikle bu sismik açıdan aktif olan fay hattı üzerinde meydana geldikleri sonucunu ortaya çıkarmıştır. Kernel yoğunluk haritaları incelendiğinde deprem yoğunluğunun genellikle İzmit şehir merkezi ve Yalova ilinin güney bölümünde yoğunlaştı̆̆ını söylemek mümkündür.

Coğrafi Bilgi Sistemleri ile konumsal olarak analiz edilen bu depremlerin hangi bölgelerde kümelenmeler gösterdiği, hangi bölgelerde dağınık yapıya sahip olduğunun belirlenmesi; gelecekte afet planlaması ve yönetimi açısından karar vericiler için önemli bir bilgi kaynağıdır. Geleceğe yönelik alınacak kararlarda ortaya çıkarılan sonuçlar doğrultusunda adımlar atmak sismik açıdan aktif olan bölgeler üzerinde yaşayanlar için olas1 depremlerin zararlarının azaltılmas1 bakımından önem arz etmektedir. Tarihsel deprem verileri ile güncel verilerin tutulduğu coğrafik veritabanları sayesinde belirtilen mekânsal analizlerin yanısıra; CBS teknolojisi ile depremle bağlantılı karmaşık mekanizma ve etkileşimleri ortaya çıkarmak amacıyla yapilacak konumsal modellemenin etkin biçimde öngörülmektedir. gerçekleştirilebileceği

\section{KAYNAKÇA}

Affan, M., Syukri, M., Wahyuna, L., ve Sofyan, H. (2016), Spatial Statistic Analysis of Earthquakes in Aceh Province Year 19212014: Cluster Seismicity. Aceh International Journal of Science and Technology, 5(2), 54-62.

Al-Ahmadi, K., Al-Amri, A., ve See, L. (2013), A Spatial Statistical Analysis of the occurence of earthquakes along the Red Sea floor spreading: Clusters of Seismicity. Arabian Journal of Geosciences, 7(7), 2893-2904.

Ayday, C., Yaman, N., ve Göçmez, A. (2015), 1900-2015 Aras1 Deprem Dış Merkez Verileri ile Eskişehir İli Deprem Risk Analizine Katkılar. TUFUAB VIII. Teknik Sетровуити, 21-23 Mayıs, Konya.

Bakak, Ö. (2016), 2005 Sığacık Körfezi (İzmir) Depremlerinin Mekansal Değerlendirilmesi. Yerbilimleri, 37(1), 5163.

Çevre ve Şehircilik Bakanlığı, Kocaeli Valiliği Çevre ve Şehircilik İl Müdürlüğü (2011). Kocaeli İl Çevre Durum Raporu.

Erdoğan, S. (2010), Epidemiyolojide CBS Uygulamaları: Konumsal Kümeleme Yöntemlerinin Karşılaştırılması-Menenjit Örneği. Harita Teknolojileri Elektronik Dergisi, 2 (2), 23-31.

Faenza, L., Marzocchi, W., Lombardi, A.M., ve Console, R. (2004) Some insights into the time clustering of large earthquakes in Italy. Annales De Geophysique, 47(5), 1635-1640. 
Gedik, İ., Pehlivan, S., Timur, E., Duru, M., Altun, İ., Akbas, B., Özcan İ., ve Alan, İ. (2004), Kocaeli Yarımadası Jeolojisi. MTA raporu.

Han, S., Ishioka, F., ve Kurihara, K. (2008) Detection of hotspot for Korea earthquake data using echelon analysis and seismic wave energy. Journal of the Faculty of Environmental Science and Technology, 13(1), 51-56.

Holden, L., Sannan, S., ve Bungum, H. (2003), A stochastic marked point process model for earthquakes. Natural Hazards And Earth System Sciences, 3, 95-101.

İlçi, V. (2013), Trafik Kaza Kara Noktalarının Mekansal İstatistiksel Yöntemlerle Belirlenmesi: Afyonkarahisar-Konya Örneği. Yüksek Lisans Tezi, Afyon Kocatepe Üniversitesi, Fen Bilimleri Enstitüsü, Afyon, Türkiye.

Mitchell, A. (2005), The ESRI Guide to GIS Analysis, Volume 2. ESRI Press.

Pei, T., Zhua, A.X., Zhou, C., Li, B., ve Qin, C. (2007) Delineation of support domain of feature in the presence of noise. Computers \& Geosciences, 33, 952-965.

Pei, T. (2011) A nonparametric index for determining the numbers of events in clusters. Mathematical Geosciences, 43, 345-362.

Shurygin, A M. (1993), Statistical analysis and long-term prediction of seismicity for linear zones. Mathematical Geology, 25(7), 759772.

Tağıl, Ş., ve Alevkayalı, Ç. (2013), Ege Bölgesinde Depremlerin Mekansal Dağılımı: Jeoistatistiksel Yaklaşım. Uluslararası Sosyal Araştırmalar Dergisi, 6(28), 370379.

Vasudevan, K., Eckel, S., Fleischer, F., Schmidt, V., ve Cook, F. A. (2007) Statistical analysis of spatial point patterns on deep seismic reflection data: a preliminary test. Geophysical Journal International, 171(2), 823-840.

Yakar, M. (2011), Nüfus Dağılımının Mekansal Analizi: Afyonkarahisar ili Örneği. Uluslararası Sosyal Araştırmalar Dergisi, 4(19), 389-406.
Zimeras, S. (2008) Exploratory point pattern analysis for modeling earthquake data. $1 s t$ WSEAS International Conference On Environmental And Geological Science and Engineering, 11-13 September, Malta. 